\section{Melchizedek in Jewish Apocalyptic Literature}

\section{Loren T. Stuckenbruck}

Protestant Faculty of Theology, Ludwig-Maximilians-Universität München, Germany
Journal for the Study of the New Testament 2018, Vol. 4I(I) 124-138

(C) The Author(s) 2018

Article reuse guidelines: sagepub.com/journals-permissions DOI: I0.I I77/0I42064XI8788983 journals.sagepub.com/home/jsnt

๑SAGE

\begin{abstract}
The study of especially apocalyptic traditions from the Second Temple period that are concerned with the figure of Melchizedek throws light on a vitality of interest that presupposes but is no longer simply dependent on the pre-texts of Gen. 14 and Ps. IIO in the Hebrew Bible. Although the epistle to the Hebrews is clearly influenced by these pre-texts, the latitude its author takes in focusing on Jesus as both priest 'after the order of Melchizedek' and as Son may be said to have been shaped by the kind of creative and imaginative engagement with tradition reflected in other Second Temple texts.
\end{abstract}

\title{
Keywords
}

I I QMelchizedek, book of Jubilees, epistle to the Hebrews, Genesis Apocryphon, Slavonic Enoch, Songs of the Sabbath Sacrifice, Visions of Amram

\section{Introduction and Approach}

References to a figure called 'Melchizedek' in the text of Hebrews in the NT and other Second Temple sources have posed many questions for scholars. As is well known, in Hebrews the author presents Jesus' priesthood no less than five times in three contiguous chapters as being 'after the order of Melchizedek' (Heb. 5.6, $10 ; 6.20 ; 7.11,17)$, supplemented by three further explicit references $(7.1,10,15)$. While it remains undisputed that Christology provides the point of departure for the appearance of Melchizedek within ${ }^{1}$ the argument of Hebrews, it is less clear

1. For focused comparisons between the presentation of Jesus in Hebrews and the figure of Melchizedek in Second Temple literature, see the discussions and evaluations of secondary literature in esp. Aschim 1999: 128-47; Mason 2008: 138-203. I wish to thank my colleagues

\section{Corresponding author:}

Loren T. Stuckenbruck, Ludwig-Maximilians-Universität München, Protestant Faculty of Theology,

Geschwister-Scholl-Platz I, 80539 Munich, Germany.

Email: Loren.Stuckenbruck@LMU.de 
whether the author (a) essentially takes two passages referring to Melchizedek of the Hebrew Bible as a point of departure (cf. Gen. 14; Ps. 110), ${ }^{2}$ (b) relies on one or more ways in which Melchizedek traditions developed during the Second Temple period (with the latter serving as implicit co-interlocutors) or (c) simply adds to an already diverse ensemble of conversation current in his time. As it is not clear that these possibilities are mutually exclusive, the discussion to follow shall briefly set out issues that arise when one regards Hebrews as an imaginative receiver and fashioner of tradition that was alive and well during its time of composition. Therein I shall argue that the question of which traditions Hebrews may have 'relied' or 'depended' on, with an attendant focus on influences upon the text, does justice to understanding neither Hebrews nor Second Temple sources that, as Hebrews, do not reflect static perspectives but offer snapshots of living tradition instead. Since the text of Hebrews at least shows awareness of Gen. 14 and Ps. 110, we do well to begin by briefly posing interpretive issues of these traditions before considering some of the Second Temple materials themselves.

\section{Genesis I4 and Psalm IIO}

The discourse of Hebrews as it relates to these 'biblical' intertexts has been considered in many scholarly studies. ${ }^{3}$ However, how they might have been catalytic or formative in themselves is an open matter that depends largely on where one thinks the interpretive issues reside in these traditions as well as on what they may have generated for audiences before and after the turn of the Common Era. Following brief attention to Gen. 14, which served as a pre-text for some later Melchizedek traditions (Josephus, Philo, Eupolemus, and Jubilees), I offer a more detailed overview of Ps. 110, given its prominence throughout Hebrews as a whole.

\section{Genesis 14.17-24}

This first mention of a priestly figure in Genesis narrates an encounter between Melchizedek and Abram following the latter's defeat of several kings. Here Melchizedek is called 'King of Salem' and 'priest of the God Most High' (14.18), both names of which, in addition to the proper name itself, are taken up and

Prof. Friedhelm Hartenstein and Dr Alma Brodersen for insights during the course of a joint seminar on the reception of the Psalms in the Hebrew Bible and Second Temple Judaism that have contributed to the framing of questions in this article.

2. For a reductionistic argument along these lines, see Cockerill 2008: 126-44.

3. Among frequently used commentaries, see the still useful overviews by Spicq 1952: I, 33050; Michel 1966: 151-65; Attridge 1989: 23-25; Lane 1991: I, cxii-cxxiv; Koester 2001: 115 18. See further Moffitt 2011: 77-97. For a survey of secondary literature on the contribution of the 'Old Testament' to Hebrews' structure, see Compton 2015: 72-81. 
interpreted in Heb. 7.1-3 (cf. esp. v. 2). Several elements of the storyline, embedded as it is within the early part of the Abraham narrative, have fueled speculation that would consider Melchizedek as a figure in his own right, that is, as one whose ultimate significance relates to but is not bound by the text of Gen. 14: (1) the terminological correspondence between 'Salem' and 'Jerusalem' (implied in the larger context of Hebrews; cf. 12.22); (2) the unexplained attribution to Melchizedek of a status as one to whom Abram offers tithes (cf. Heb. 7.4) and as one who offered provision; and (3) the absence of any detail about his ultimate origin (cf. Heb. 7.3). This is variously demonstrated not only by Hebrews and other Second Temple texts discussed below, but also already by the text-traditions related to Ps. 110.

\section{Psalm I I0}

Psalm 110, unlike Gen. 14, is not formulated as a narrating storyline; it is instead a 'royal psalm', ${ }_{4}$ the superscription of which (in both the Hebrew and Greek traditions) is linked to the figure of David. In contrast to its obvious use in Hebrews and other writings of the NT, ${ }^{5}$ it is nowhere explicitly cited in other Second Temple tradition, ${ }^{6}$ though it may be possible to discern the occasional allusion. ${ }^{7}$ Although the significance of Ps. 110 in the latter may need to be reconsidered (as below), this contrast raises a twofold question: the extent to which the author of Hebrews interacts with the psalm idiosyncratically (or at least in continuity with other traditions preserved among NT writings) and whether the author's interpretation of Ps. 110 interacts with other Melchizedek traditions outside the Jesus movement, the point to be explored in what follows.

\section{Hermeneutical Issues Arising from Psalm I 10}

It is worth making a few comments on ambiguities in the text of Ps. 110, as this prepares for a consideration of the degree to which it may have played a role in any of the Second Temple literature outside the NT and, to that extent, whether Hebrews participated in contemporary interpretation. After a third

4. Concerning the difficulties of definition and for a survey of scholarly discussion, see Starbuck 1999: 19-66.

5. Cf. Martin Hengel's overview of the significance of Ps. 110 for Christology in the NT in Hengel 2004: 119-226.

6. This point was so emphasized by Hengel, in order to demonstrate Ps. 110's significance for the claim of Jesus' earliest followers that their crucified leader was given a unique place of honor, that he minimized 'pre-Christian' use of the psalm in relation to the exaltation of any other figure; cf., e.g., Hengel 2004: 203, 207; cf. also Lee 2005: 205.

7. As noted by Mason 2008: 146 who, however, rightly mentions the interest in 11QMelchizedek in the psalm (cf. 168-90). 
person opening in which a speaker/writer states that 'the LORD (YHWH) said to my lord (Adonai), "Sit at my right hand until I make your enemies your footstool", the text proceeds by letting the second person singular take on a life of its own in the main part of the psalm (vv. 2-5a), until it closes in the third person with references to what 'Adonai', 'who is at your right hand' (whether the right hand of YHWH or of the king) is expected to do when he defeats kings and exercises judgment over the nations. Within the main part of the psalm, the figure addressed in the second person is told in the Masoretic pointing that 'from the womb of the morning to you shall be your youth' (v. 3b), whereas the consonants in 'your youth' (ילדתיך) could also be taken to mean 'I have given you birth' (as in the LXX: 'from the womb before the morning star I have given

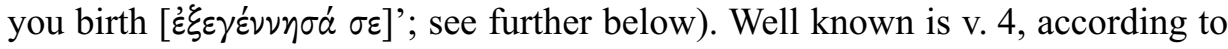
which the Lord (YHWH) 'has sworn and will not change his mind' as a figure, perhaps the Adonai of v. 1, is designated 'priest forever according to the order of Melchizedek' (so LXX, also a possible construal of MT), though the text itself could also be translated as addressed to a new figure, Melchizedek himself: 'you aברתי ace a priest forever according to my order, O Melchizedek (with $-y$ in dibrāti)', which in turn would form a parallel to the Lord's (YHWH) addressing to Adonai in v. 1.

There are, then, a number of figures or characters, explicit or implied, in play in the text, and the extent to which they can be identified with each other allows for plenty of interpretive play. There is (1) David, who, as already noted, is referred to in the superscription (v. 1); (2) the narrator at the beginning of v. 1 (also possibly, though not certainly, in vv. 5b-7); (3) YHWH (vv. 1, 2 and 4); (4) Adonai in vv. 1 and 5a, where it is not clear whether Adonai is an equivalent for YHWH, the same Adonai as mentioned in v. 1, an equivalent to Melchizedek in v. 4, or a separate being altogether; and, finally, (5) Melchizedek, who suddenly appears in v. 4 and may or may not be related to Adonai in vv. 1 or 5. In all this, a context in the heavenly court is presumed. The narrator at least alludes to it, whether the main addressee of the psalm is thought to be on earth and is virtually placed at the 'right hand' of YHWH who wields power on his behalf, or is actually thought to take his seat there and so to preside alongside YHWH over events below.

Though unanticipated, the appearance of 'Melchizedek' in Ps. 110 can, despite differences and without postulating literary dependence, be thematically linked to the narrative of Gen. 14 in three main ways : both passages share (1) the double association of Melchizedek with being 'priest' and 'king' (the title 'king' is implied for the addressee in Ps. 110, which is otherwise saturated with royal imagery), (2) the motif of defeating enemies who are designated as 'kings' (cf. Gen. 14.17; Ps. 110.5) and (3) a link with Jerusalem (at least so during the Second Temple period; cf. Josephus, J.W. 6.438; Ant. 1.180), with Melchizedek designated 'king of Salem' in Gen. 14.18 and the royal addressee's powerful 
scepter being sent out among his enemies 'from Zion' in Ps. 110.2. With Gen. 14 in the background, an audience of Ps. 110 could have inferred that Melchizedek played a role in Abram's defeat of kings rather than simply, as in Gen. 14, featuring in the narrative after the fact. Additionally, with later Melchizedek traditions in mind, we may observe that the available Greek translation tradition fits well into an eschatological context, more so than the Masoretic tradition. ${ }^{8}$ The Greek version thus illustrates how, in another socio-political or ideological context, the Hebrew could be received.

Though the problem of coherence among the elements and figures in Ps. 110 might lead to source-critical solutions, we are more interested in what such a baffling text can generate in terms of interpretive speculation. Most NT specialists are well versed in the importance of Ps. 110 for early convictions that Jesus, after his death, was exalted to 'the right hand' of God. ${ }^{9}$ Except for Hebrews, however, none of the many quotations of and allusions to Ps. 110 mentions Melchizedek. What is more, there is no known formal quotations of the text in Second Temple writings outside the NT, nor is any part of the text preserved among fragments to the Psalms among the Dead Sea materials. At the same time, however, several writings do refer to Melchizedek (who in the case of two writings can be plausibly reconstructed). From what do these references derive? If not from traditions as yet unknown, it is not unlikely that, to one extent or another, they link back to Gen. 14, to Ps. 110, or possibly draw on both. Such a derivation is much easier to explain in relation to Gen. 14 (in the cases of paraphrastic retelling) and more difficult in relation to Ps. 110 (where we can at best only speak of allusions). Significant in relation to Ps. 110 are, simply put, two things: (1) the mere occurrence of Melchizedek's name in a way that goes well beyond the Gen. 14 narrative (whether Hebrew, Greek or other versions) and (2) the reference to Melchizedek in the context of discourse emanating in or from the heavenly court, thus opening up the possibility to perceive Melchizedek as a heavenly being. Hence the possible use of or allusion to the psalm in Second Temple literature outside the NT is of particular importance.

\section{'Melchizedek' and Second Temple Writings}

Taking Genesis 14 and Psalm 110 as points of departure, we turn to six sources in order to discern what sorts of speculative developments have taken place among apocalyptically orientated circles. ${ }^{10}$ The pertinent texts are Jub. 14.2527, Genesis Apocryphon XXII, 12-17, Visions of Amram at 4Q544 2.15 and

8. As emphasized for Ps. 110 in Schaper 1995: 101-107.

9. In addition to Hengel's work (see n. 5), cf. Hay 1973.

10. Since Josephus and Philo are concerned more with Gen. 14 alone rather than Ps. 110, I reserve a consideration of these sources for another study; for now, cf. Mason 2008: 154-64. 
3.3, Songs of the Sabbath Sacrifice at 4Q401 11.3, 11Q13, and Slavonic Enoch (2 En.) 71 .

\section{Jubilees 13}

Beginning with Jubilees, we note that the retelling of the account more readily known through Gen. 14 makes no mention at all of Melchizedek (cf. Jub. 13.25). ${ }^{11}$ Instead, the text refers to 'priests' in the plural. It is to God, in the first instance, that a servant of Abram's house offers the tenth of the firstfruits from Abram, before the text specifies that, as God ordained, the tithe is given to the priests who serve before him. Interesting here, however, is the note, immediately following, that 'the Lord ordained it (i.e. the tithing of firstfruits) as an ordinance forever (Ge'ez: wa-'egzi'abher śar'o śer'at la-'alām) 'so that they receive it forever'. In the next verse, the text reads that 'the Lord ordained it for generations forever' (tewled la- 'alām śar'o). The note has no equivalent in Gen. 14, but does come close to the language of Ps. 110.4: 'priest forever (la-'alām) after the order of Melchizedek' (though Ge'ez of the latter has śimatu la-malka sedeq). It is not impossible that the reference to an eternal ordinance (with the noun) in $J u b .13 .25$ presupposes an underlying Greek $\tau \dot{\alpha} \xi \mid \zeta$, which is the Greek term for 'order' in Ps. 110.4. If there were an allusion to Ps. 110 at all, that would strengthen the assumption that the text was aware of Melchizedek (perhaps not only in Gen. 14) and deliberately omitted this figure from the account in order to focus more exclusively on the practice of giving the tithe to $\mathrm{God}$, as administered through priests who serve him.

\section{Genesis Apocryphon}

The Jubilees narrative contrasts markedly with the retelling of the tradition in Gen. 14 in Genesis Apocryphon (1Q20 XX). With respect to Melchizedek, the Aramaic text at 1Q20 XX, 12b-17 adheres, with a few exceptions, ${ }^{12}$ to what we find in Genesis and preserves no recognizable echo of Ps. 110.

The next two texts are important, not so much for their explicit attestation of Melchizedek, but for the fact that many scholars have reconstructed the name in the lacunae.

11. Several Ge'ez mss (nos. 38c $, 40,45$ in VanderKam's edition, see here below), which add a reference to Melchizedek, probably do so to harmonize with Gen. 14. For this reason, one must be cautious in restoring Melchizedek to the narrative as proposed by VanderKam 1989: I, 82 and II, 81-82 (a proposal followed by Mason 2008: 149-51). The discussion here follows only the Ge'ez version, as neither Dead Sea Hebrew fragments nor the Latin text of the undertext in Codex Ambrosianus preserves the text in question.

12. In comparison to Gen. 14, the few differences in 1Q20 XX renders Melchizedek, according to Mason 2008: 149, as 'not quite the mysterious figure he is in Gen 14 or Heb 7'. 


\section{Visions of Amram (4Q543-547, 548-549?)}

In the Aramaic Visions of Amram text, ${ }^{13}$ the patriarch sees in a dream vision two angelic beings contesting for power over him in advance of his death (4Q543 5-9; 4Q544 1.9-10). He asks them who they are and is given to see them; in turn, he is asked to which of them he belongs. The two beings, who are presented in stark contrast to one another, each carries three names that are only partially preserved (4Q544 1.13; 4.2). Among the three names, only one is preserved for the malevolent angel, Melkireša' (3.13), who is given dominion over all darkness (3.15; cf. 5.10). More characteristics on this side of the equation come into play if 4Q548 can be assigned to the work; in that case, the angel would be associated with everyone who is a fool (כל כסל) and wicked (4Q548 1 II-2.12: רשיע), as well as with 'all the children of darkness' and 'of deceit' (4Q548 1 II-2.8, 12-13). His opposite has dominion over all light (4Q544 3.15-16) and is associated with everyone who is 'wise' and 'true' (or: 'righteous' קשיט), as well as with 'all the children of light' who are also called 'children of blessing' (4Q548 $1 \mathrm{II}-2.5$ ) and possibly, though not certainly, 'children of r[ighteousness' (4Q548 1 II-2.7). Hardly anyone, since the seminal article by J.T. Milik (1972: 95-144), has cast serious doubt on the possibility that one of the names of this figure was Melchizedek. However, if רש] in 4Q548 1 II-2.12 (which is the probable restoration) can be coordinated with Melkireša', the adjective in parallel position of the same line, קשיט, would make it possible to consider whether or not Melki-qušt, instead of Melki-zedek, is the angel associated with light. ${ }^{14}$ This is a point further suggested by the apparent absence in the preserved text of an allusion to either Gen. 14 or Ps. 110. Nonetheless, if Melki-zedek is the name to be restored, the presentation of this angelic being has taken on a life of its own; he has become the subject of speculation within a cosmological-ethical framework of opposing figures who, as 'the prince of lights' and 'the angel of darkness' in 1QS III, ultimately come under the rule of God. This being can hardly be derived from the figure of Melchizedek as presented in Gen. 14; by contrast, though remaining unclear, the context of a heavenly court in Ps. 110 might have led to the construal of such a 'Melchizedek' (in the lacuna) as a heavenly being who is in conflict with the enemy (understood in Ps. 110.5 as 'kings'). The work, which seems to have been concerned with the establishment of the priesthood, refers to a succession of seven figures (reconstructed as being Abraham all the way to Aaron) who are favored by God (4Q545 4). The text states that the seventh of these and last (who may be either Moses or Aaron; 4Q545 4.15, 18) 'shall

13. For a discussion of the writing as a whole and an edition of the manuscripts, see, respectively, Puech 2001: 283-88 and 289-405.

14. On the association of the Aramaic root $q-\check{s}-t \underline{t}$ alongside $s-d-q$ with 'righteous(ness)', see, e.g., Stuckenbruck 1990: 13-49 (here 34-35 and 42). 
be chosen as a priest forever' (4.19). The designation 'priest forever', which is surprisingly rare (cf. also only 1 Macc. 14.41 - referring to Simon; the expression occurs nowhere else among the Dead Sea Scrolls, in Philo, or Josephus), would be consistent with the designation 'priest forever according to the order of Melchizedek' in Ps. 110.4 and thus with a reconstruction of Melchizedek as the good angel in Visions of Amram. In his DJD edition, Émile Puech has at one crucial point reconstructed the text to 4Q545 4.16 with Gen. 14 in mind (without indicating so), when he has the angelus interpres tell Amram that Aaron will be a 'holy priest [to the God Most High]' (Gen. 14.18; Puech 2001: 34243). This reconstruction implies that, similar to Hebrews' use of Melchizedek to underscore Jesus' privileged status as priest, the priesthood of Aaron receives its character through an allusion to that of Melchizedek. Such may at least also be inferred from the possible reference to Aaron as 'priest forever' in 4Q545 4.19.

So, while I am not sure that recipients of Visions of Amram would have recognized an allusion to Ps. 110 in the expression 'priest forever', such may very well have been so if the good angel bore the designation 'Melchizedek' or the equivalent.

\section{Songs of the Sabbath Sacrifice ${ }^{15}$}

In Songs of the Sabbath Sacrifice, the name 'Melchizedek' has been restored three times in 4Q401 at 11.3 and 22.3 and in 11Q17 2.7, respectively. ${ }^{16}$ The latter reference is completely opaque and has no literary context to support the restoration (simply: ] malki[) other than what is restored in the preceding lacuna on the basis of proposed parallels. The second fragment in 4Q401 22.3 also has no basis for the reconstruction other than what is in the text itself: צדק preceded by כ of which the kaph is more of a reconstruction than an indisputable reading. The text in 4Q401 11.3 offers a little more; it reads:

$$
\text { מלכי [צדק כוהן בעד[ה }
$$

Although the term צדק occurs among the extant 'non-biblical' Dead Sea texts at least 228 times and 119 times in the Masoretic Tradition of the Hebrew Bible, in no instance other than here and when the name Melchizedek occurs is it ever combined with the noun 'priest'. There are no grounds for certainty, but the statistical plausibility of the reconstruction allows at least for one to imagine what a being by such a designation is doing in the Songs. Melchizedek, in this

15. References to and reconstruction of the text below follow the edition of Newsom 1998: 173-400.

16. Cf. Newsom 1998: 205 and 233; on the restoration in 11Q17, see Davila 2000: 133 and 166, who notes the possibility of other reconstructions. 
instance, would be a priestly figure positioned within the heavenly congregation. Given the macro-context of the fragment, the worship of God as King in the heavenly temple, Melchizedek's role would have to do with the administering of the cult in this setting. The Songs refer frequently to priests in the plural as well as to 'priesthood' and 'priesthoods' (the latter probably seven in number), but only one further time in the preserved material to a 'priest' in the singular; that reference is to 'the Head Priest who draws near' (רוש מכוהן קורב, 4Q403 1 II, 24), and there are other beings associated with priesthood in the document (without explicitly being called כוהן 'priest'). Whether there is any link between the restored Melchizedek and this Head Priest cannot be determined, though the heavenly worship depicted in the work is frequently described in terms of its being 'forever' or 'eternal'. If Melchizedek is in view at all, then his function as one who, among others, acts in a priestly capacity within a highly idealized context may be reflective of Ps. 110.4. ${ }^{17}$ By contrast, the divine name found in Gen. 14, 'Most High' (אל עליון), occurs nowhere among the Songs.

\section{I QMelchizedek (I IQI3)}

We now turn to 11Q13, often called 11QMelchizedek due to the prominence of the figure who is named no less than five, perhaps six times. The text refers to a number of activities on the part of Melchizedek that are to take place 'at the end of days' (11Q13 II, 4). Though this temporal framework is consistent with the eschatologizing Greek version to Ps. 110 (LXX Ps. 109; cf. n. 8 above), the text nowhere quotes the psalm while, at the same time, formally citing and interpreting a number of other texts. These texts, together with the emphasis drawn from them, consist of the following:

- Lev. 25.13 and Deut. 15.2 (the announcement of the jubilee year when possessions shall be returned to the owner; 11Q13 II, 2-4);

- Isa. 61.1-3 (v. 1, proclamation of liberty to those captive [11Q13 II, 6]; v. 2, the year of Melchizedek's [not YHWH's!] favor [II, 9]; v. 3, comfort for those who mourn [II, 19-20]);

- two Psalms called 'songs of David' (שירי דויד): (1) Ps. 82.1-2 (v. 1, God [אלחים] - interpreted as Melchizedek - will take his stand in the divine assembly to judge the nations, interpreted as Belial and the spirits who belong to him; v. 2, divine vengeance against the wicked will not be unduly delayed [1Q13 II, 10-13]) and (2) Ps. 7.8-9 (God [אלהים] - also interpreted as Melchizedek - will judge the nations; 1Q13 II, 10-11);

17. Even if this holds, however, Melchizedek does not receive an emphasis one might expect; the figure, though in an important capacity, simply appears as part of the heavenly entourage of worshippers. 
- Isa. 52.7 (one bringing good news will speak to Zion, 'your God [אלהיכה] is king', in which it is not clear whether Melchizedek is the bringer of good news or 'your God' [1Q13 II, 15-17, 22, 24-25]); ${ }^{18}$

- Dan. 9.25 (the probable text cited, given the introduction [II, 18], which identifies the bringer of good news in Isa. 52 with a spirit-anointed one about whom Daniel spoke as anticipated after seven weeks); and, significantly,

- an unidentifiable instruction (if it is not a previously unknown text variant to Lev. 25.9) to blow the shophar 'in the] whole [1]and', which will signify or, better, enact the defeat of Belial (II, 25).

In addition to these text traditions, 11Q13 links the remission of the jubilee and the freeing of the captives to the forgiveness of iniquities and an eschatological atonement 'at the e[nd of] the tenth [ju]bilee' on behalf of 'the children of G[od and] the m[e]n of the lot of Mel[ki-]zedek' (II, 4-8). Thus, although Melchizedek is not explicitly called 'priest' in the extant text, a priestly function for him is assumed.

It is possible that the now lost text somewhere cited Ps. 110, which would have furnished the writer with a celestial framework within which to imagine the activity of Melchizedek. Even without such proof, however, a number of elements in 11Q13, even if they overlap with texts explicitly quoted, are reminiscent or relate to Ps. 110, and these in turn can be brought into conversation with the Christology of Hebrews.

First, there is the dual function of Melchizedek as both priest (implied) and king (cf. Isa. 52.7). A reading of Ps. 110 would have made it possible to assume the identification of Melchizedek with the royal figure addressed in v. 1, while the psalm at v. 4 is read as an address to Melchizedek himself ('you are a priest forever according to my ordinance, O Melchizedek'), so that he takes center stage. Of course, the dual function is also found in Gen. 14, though it is Ps. 110 which 'kicks the tradition upstairs' into the heavenly council. Although Hebrews does not quote Ps. 110.4 in this way, it is significant that the catena exposition of ch. 1 is framed by two addresses by God to Jesus taken from Pss 2 and 110, respectively: (1) 'you are my Son; today I have begotten you' (Ps. 2.7) in 1.5 and (2) 'sit at my right hand until I make your enemies your footstool' (Ps. 110.4) in 1.13. This is significant, as the same two psalm texts are placed contiguous to one another in Heb. 5.5-6, which in turn presupposes the Greek text to Ps. 110.3.

Second, and perhaps the weakest link since it only rests on inference, Melchizedek is associated with God. We have seen that the designation 'elohim (אלהים) is derived from Pss 7 and 82 as well as from Isa. 52. Though the term occurs nowhere in Psalm 110, the possible link between Melchizedek and

18. For the latter, not implausible reconstruction, cf. García Martínez, Tigchelaar and van der Woude 1998: 221-41 and Steudel 2011: 182-83. 
Adonai (cf. vv. 1, 5a) and the fluidity between Adonai and YHWH in the psalm are consistent with the overall presentation in 11Q13, in which Melchizedek, YHWH (cf. the strong allusion to Isa. 61.2 in 11Q13 II, 9) and 'elohim are interwoven. Similarly, Hebrews coalesces its presentation of Jesus with 'God' by using the text of Ps. 45.6 to address Jesus in this way (Heb. 1.8).

Third, as with the royal figure in Ps. 110.2, Melchizedek's rule as king is located in 'Zion' (II, 16, 23; cf. Isa. 52.7). Although Hebrews declares 'Mount Zion, the city of the living God, the heavenly Jerusalem' as the ultimate destination of obedient believers (Heb. 12.22), it does not receive an emphasis as the location of Jesus' activity and session to God's right hand, other than through his association with Melchizedek as 'king of Salem' (7.2).

Fourth, as the royal figure in Ps. 110 (vv. 1, 3 and 5-6), Melchizedek presides over the conflict against enemies (1Q13 II, 13-14). If Gen. 14 is in view at all in the background of Ps. 110 and of 11Q13, Melchizedek's role in Gen. 14 in relation to the enemy has been transformed from being passive into involvement as an active eschatological agent. Though the final outcome is ultimately attributed to God (cf. Heb. 1.13), the obedience of Jesus is highlighted even more (cf. Heb. 10.9, 12, 13a; see also 10.13, where God's activity in Ps. 110/LXX 109.1 ['I put'] is presented in the passive 'they [the enemies] will be put').

Fifth, Melchizedek is an agent of divine judgment (what Adonai does in Ps. 110.6 - ידין בגוים; 11Q13 9-13 [drawing more immediately, however, on Ps. 82.1 and esp. Ps. עמים ידין 7.9 בגוום and 23). In Hebrews, by contrast, for all his association with God as Son, Jesus is never directly associated with judgment.

While Ps. 110 is not obviously there, a number of the elements that singly relate to other traditions can be said to cohere within its framework, especially as only Ps. 110 (beyond Gen. 14) mentions Melchizedek specifically. Significantly, the implicit fluidity between designations in Ps. 110 and its growing eschatological reading (as in the Greek version) carry over into the same in 11Q13, though with the specific designation 'Adonai' no longer in play and the focus on 'the end of days' far more pronounced. ${ }^{19}$

\section{Slavonic Enoch 7I}

I would like to mention, very briefly, a final text from Slavonic or 2 Enoch, the date and origin of which (whether non-Christian Jewish or ultimately Christian)

19. Philo's allegorical treatment of Melchizedek moves in a very different direction from the presentation of him in 11Q13 by clearly emphasizing that 'the Most High God' for whom Melchizedek served as priest (Leg. 3.79-82; cf. Gen. 14) is 'one' and 'there is no other beside him' (Deut. 4.39); contra Davila 2000: 165. 
can be disputed. ${ }^{20}$ The text, from ch. 71, tells of the birth of Melchizedek before the Great Flood and, in a way, has its closest narrative links with the parallel stories about Noah's wondrous birth told in 1 En. 106-107 and Genesis Apocryphon (1Q20 II-V). The storyline picks up several elements that are reminiscent of Ps. 110 , most obviously with Melchizedek being a priest of singular importance (2 En. 71.19-20, 29 ['head of priests'], 31 ['a great priest'], 33). In addition, Slavonic Enoch refers to 'another Melchizedek' who will exist 'in the last generation' as a 'great high priest' (71.34-35, 37; cf. Heb. 4.4; further 1 Macc. 13.24; and Philo, Somn. 1.219), which reflects the temporal setting assigned to his activity in 11Q13.

Most interesting, however, is why the account in Slavonic Enoch has chosen to focus at all on Melchizedek's birth. I think that the answer lies rather directly in the text of Ps. 110.3: the Greek tradition, reading a Hebrew Vorlage in a particular way, states that, "with you is the rule on the day of your strength, and among the shining lights of the holy ones I have begotten you before the morning star'. Instead of the Masoretic pointing of yaldutekah (ילדתיכה, 'your youth'), the Greek presupposes on the basis of the same consonants yelidtikah (i.e. also ילדתיכה) which, in turn (among the Psalms), is reminiscent of Ps. 2.7 (also a royal psalm linked with Zion and relating to conflict with kings): 'today I have begotten you'. ${ }^{21}$ Not only the story as a whole, but also 2 En. 71.19 refers to his

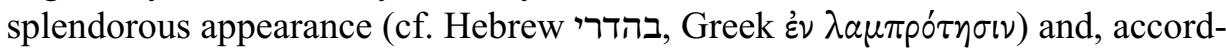
ing to 71.30, Nir praises God for having created 'a great priest in the womb' of Sopanima his wife. As with the birth story as a whole, both these elements, though unobtrusive in the storyline itself, may have been inspired by Ps. 110.3 as found in the Greek. The appropriation of motifs from Ps. 110 in Slavonic Enoch, however, shows little parallel to the text of Hebrews, except for the emphasis on 'birth', which can be traced back to the Greek version to v. 3 (and, for Hebrews, more explicitly to Ps. 2.7).

\section{Conclusion}

The above review of some Second Temple texts illustrates that the name 'Melchizedek' was applied in a wide variety of ways, often, though not always, inspired by details preserved in Gen. 14 and, significantly, Ps. 110 as well. Speculative interest was fueled not only by these texts, but also and especially by ways they could be read in relation to other sacred traditions, as seen in $11 \mathrm{Q} 13$,

20. See the overview of issues in Collins 2016: 301-10 (on date, 301-302) and the different perspectives by Böttrich 2012: 37-68 and Suter 2012: 117-26. The discussion here takes the translation by Böttrich 1996.

21. It may be that Hebrews' use of Ps. 2.7 in Heb. 1.5 and 5.5 ('you are my son; today I have begotten you') also echoes the Greek version of Ps. 110.3. 
in which a combined series of intertextual relationships has taken on a life of its own, drawing on Ps. 110 but leaving it well behind. The conflationary hermeneutic in 11Q13 makes it possible for the text to identify or link Melchizedek, both explicitly and implicitly, with a number of functional labels: 'elohim (Pss. 7; 82; Isa. 52), YHWH (implied from the use of Isa. 61.1), priest (Ps. 110), king (Isa. 52), bearer of good news (Isa. 52) and anointed one (Dan. 9). A comparable hermeneutic may be in play in Hebrews, in which the overt use of many text traditions does not seem idiosyncratic and results in a focus on Jesus as Son and priest. While Hebrews reflects the influence of already well-established traditions with respect to the Christological use of Pss 2 and 110, the diversity of presentations involving Melchizedek, aside from allusions referred to here, do not in any way indicate a development of tradition within a continuum (unless, as in Genesis Apocryphon, to a small extent in Philo, in Josephus and in Heb. 7.11, we have to do with a retelling of Gen. 14). At the same time, texts that mention Melchizedek, such as Visions of Amram and Songs of the Sabbath Sacrifice (if admissible), 11QMelchizedek, Hebrews and Slavonic Enoch reflect, share and participate in a Zeitgeist no longer completely moored to their pretexts in the Hebrew Bible. While speculative exegesis of received text-traditions continues to play a role, emerging cosmologies, taking their cue from heavenly discourse and based on cognitive and perhaps practiced interactivity between heaven and earth, inspired writers to generate narratives within distinguishable socio-religious contexts. Here, the determination of influences among roughly contemporary traditions on Melchizedek is less significant than a recognition of their particularity. It is here that Hebrews, with its dual emphasis on Jesus as Son and as priest 'after the order of' a Melchizedek whom God has begotten (Greek Ps. 109.3), assumes its unusual, though not tradition-historically implausible, character. Second Temple Jewish traditions provide a plausibility structure that includes the question of intertextual influence but cannot be reduced to it.

\section{References}

Aschim, Anders

1999

'Melchizedek and Jesus: 11QMelchizedek and the Epistle to the Hebrews', in Carey C. Newman, James R. Davila and Gladys S. Lewis (eds.), The Jewish Roots of Christological Monotheism (JSJSup, 63; Leiden: Brill): 129-47.

Attridge, Harold W.

1989

The Epistle to the Hebrews (Hermeneia; Philadelphia: Fortress Press).

Böttrich, Christfried

1996

Das slawische Henochbuch (JSHRZ, V/7; Gütersloh: Gütersloher Verlagshaus).

2012

"The Book of the "Secrets of Enoch" (2 En): Between Jewish Origin and Christian Transmission', in Andrei A. Orlov and Gabriele Boccaccini (eds.), Perspectives on 2 Enoch: No Longer Slavonic Only (Studia Judaeoslavica, 4; Leiden: Brill): 37-68. 


\section{Cockerill, Gareth Lee}

2008

'Melchizedek without Speculation: Hebrews 7.1-25 and Genesis 14.17-24', in Richard Bauckham, Daniel Driver, Trevor Hart and Nathan MacDonald (eds.), A Cloud of Witnesses: The Theology of Hebrews in its Ancient Contexts (LNTS, 387; London: T\&T Clark): 128-44.

Collins, John J.

2016

The Apocalyptic Imagination: An Introduction to Jewish Apocalyptic Literature (3rd edn; Grand Rapids, MI: Eerdmans).

Compton, Jared

2015

Psalm 110 and the Logic of Hebrews (LNTS, 537; London: Bloomsbury T\&T Clark).

Davila, James R.

2000 Liturgical Works (ECDSS; Grand Rapids, MI: Eerdmans).

García Martínez, Florentino, Eibert J.C. Tigchelaar and A.S. van der Woude

1998

'13. 11QMelchizedek', in Qumran Cave 11. II. (11Q2-18, 11Q20-31) (DJD, 23;

Oxford: Clarendon Press).

Hay, David M.

1973

Glory at the Right Hand: Psalm 110 in Early Christianity (SBLMS, 18; Nashville: Abingdon Press).

Hengel, Martin

2004 Studies in Early Christology (repr.; London: T\&T Clark [1995]).

Koester, Craig R.

2001 Hebrews (AB, 36; New York: Doubleday).

Lane, William L.

1991 Hebrews (WBC, 47A; 2 vols.; Nashville: Thomas Nelson).

Lee, Aquila H.I.

2005

From Messiah to Pre-existent Son (WUNT, 2/192; Tübingen: Mohr Siebeck).

Mason, Eric F.

2008

'You are a Priest Forever': Second Temple Jewish Messianism and the Priestly Christology of the Epistle to the Hebrews (STDJ, 74; Leiden: Brill).

Michel, Otto

1966

Der Brief an die Hebräer (KEKNT, 13; Göttingen: Vandenhoeck \& Ruprecht).

Milik, J.T.

1972

'Milkî-ședeq et Milkî-reša‘ dans les anciens écrits juifs et chrétiens', JJS 23: 95-144.

Moffitt, David M.

2011 'The Interpretation of Scripture in the Epistle to the Hebrews', in Eric F. Mason and Kevin B. McCruden (eds.), Reading the Epistle to the Hebrews (Atlanta: Society of Biblical Literature): 77-97.

Newsom, Carol A.

1998 'Shirot 'Olat Hashabbat', in Eileen Schuller and Carol Newsom et al. (eds.), Qumran Cave 4. VI. Poetical and Liturgical Texts, Part 1 (DJD, 11; Oxford: Clarendon Press): 173-401. 
Puech, Émile

2001

'4Q543-4Q549. 4QVisions de 'Amrama-g', in Qumrân grotte 4 XXI: Textes araméens, première partie, 4Q529-549 (DJD, 31; Oxford: Clarendon Press): 283405.

Schaper, Joachim

1995 Eschatology in the Greek Psalter (WUNT, 2/76; Tübingen: Mohr Siebeck).

Spicq, C.

1952 L'Épitre aus Hébreux (2 vols.; Études bibliques; Paris: J. Gabalda).

Starbuck, Scott R.A.

1999

Court Oracles in the Psalms: The So-Called Royal Psalms in their Ancient Near Eastern Context (SBLDS, 172; Atlanta: Society of Biblical Literature).

Steudel, Annette

2011 Texte aus Qumran II: Hebräisch/Aramäisch und Deutsch (Darmstadt: Wissenschaftliche Buchgesellschaft).

Stuckenbruck, Loren T.

1990

'Revision of Aramaic-Greek and Greek-Aramaic Glossaries in The Books of Enoch: Aramaic Fragments from Qumrân Cave 4 by J.T. Milik', JJS 51: 13-49.

Suter, David W.

2012

'The Question of Dating and the Sacerdotal Traditions', in Andrei A. Orlov and Gabriele Boccaccini (eds.), Perspectives on 2 Enoch: No Longer Slavonic Only (Studia Judaeoslavica, 4; Leiden: Brill): 117-26.

VanderKam, James C.

1989

The Book of Jubilees (2 vols.; CSCO, 510-511; Leuven: Peeters). 